\title{
Pengaruh Model Experiential Learning Berbasis Eksperimen Inquiry Terhadap Pemahaman Konsep Fisika pada Siswa Kelas XI IPA MAN 1 Palu
}

\author{
Ika Nurul Fitriani, Kamaluddin dan Muhammad Jarnawi \\ ikanurulfitri@yahoo.com \\ Program Studi Pendidikan Fisika FKIP Universitas Tadulako \\ Jl. Soekarno Hatta Km. 9 Kampus Bumi Tadulako Tondo Palu - Sulawesi Tengah
}

\begin{abstract}
Penelitian ini bertujuan untuk mengetahui ada tidaknya pengaruh model experiential learning berbasis eksperimen inquiry terhadap pemahaman konsep fisika pada siswa kelas XI IPA MAN 1 Palu. Jenis penelitian yang digunakan adalah kuasi eksperimen dengan desain "The Equivalen Pretest-Posttest Design". Sampel yang dipilih dengan menggunakan teknik purposive sampling. Sampel penelitian yaitu kelas XI IPA 2 sebagai kelas eksperimen dan kelas XI IPA 3 sebagai kelas kontrol. Instrumen yang digunakan berupa tes pemahaman konsep dalam bentuk essay. Berdasarkan hasil pengolahan data, untuk kelas eksperimen diperoleh rerata skor pretest adalah 16,78 dan untuk posttest adalah 33,67 . Kelas kontrol diperoleh rerata pretest 16,11 dan untuk posttest 24,32. Berdasarkan hasil pengujian $\mathrm{N}$-Gain kelas eksperimen berada dalam kategori sedang dengan nilai $\mathrm{N}$-gain sebesar 50,00\% dan kelas kontrol berada dalam kategori rendah dengan nilai N-Gain sebesar 24,00\%. Hasil pengujian hipotesis diperoleh nilai $t_{\text {hitung }}>t_{\text {tabel }}(7,42>1,68)$. Hal ini berarti $H_{1}$ diterima dan $H_{0}$ ditolak. Dengan demikian dapat disimpulkan bahwa ada pengaruh model experiential learning berbasis eksperimen inquiry terhadap pemahaman konsep fisika pada siswa kelas XI IPA MAN 1 Palu.
\end{abstract}

Kata Kunci : Model Experiential Learning, Eksperimen Inquiry, Pemahaman Konsep Fisika

\section{PENDAHULUAN}

Upaya untuk meningkatkan mutu pendidikan terus dilakukan dan dikembangkan termasuk diantaranya peningkatan pemahaman konsep siswa pada mata pelajaran sains khususnya fisika. Penguasaan pengetahuan dalam mata pelajaran fisika tidak lepas dari pemahamanan konsep siswa itu sendiri terhadap pengetahuan yang dipelajari. Penguasaan ilmu pengetahuan dapat diartikan sebagai suatu kemampuan dimana siswa dapat menerapkan konsep yang telah dipelajari untuk memecahkan masalah yang dihadapi dalam kehidupan sehari-hari.

Kebanyakan siswa terbiasa menghafal rumus-rumus fisika berbentuk persamaan matematik daripada memahami maknanya secara fisis. Siswa cenderung mengalami kesulitan untuk memecahkan soal-soal fisika yang berhubungan dengan pemahaman konsep-konsep dasar. Pembelajaran yang memudahkan siswa dalam memahami konsep fisika adalah pembelajaran yang melibatkan siswa secara aktif. Misalnya saja guru memberi sebuah eksperimen terhadap materi fisika. Siswa melakukan suatu percobaan yang dirancang sendiri dengan bimbingan guru untuk menguji suatu hipotesis yang merupakan prediksi siswa dalam menyelesaikan masalah yang diberikan oleh guru.Dari sini, siswa dapat terlibat langsung dan berperan aktif dalam proses belajar mengajar, sehingga pembelajaran menjadi menarik, menyenangkan dan tidak menjenuhkan.

Banyak cara bagi seorang guru untuk menyampaikan materi pelajaran fisika yang dapat membuat siswa merasa senang, diantaranya adalah dengan menggunakan model dan metode yang tepat dalam kegiatan pembelajaran. Oleh sebab itu, diperlukan model pembelajaran yang dapat membuat siswa dapat mengasah kemampuannya sendiri melalui pengalaman yang mereka dapat sebelumnya sehingga memudahkan memahami konsep fisika yaitu dengan model experiential learning berbasis eksperimen inquiry.

Beberapa penelitian yang dilakukan sebelumnya ${ }^{[1]}$ model experiential learning ini siswa diajak untuk langsung merasakan dan mengamati kejadian yang ada disekitarnya dengan mengumpulkan data yang ditemukan agar siswa mampu melaporkan apa yang ditemukankan dari pengalamannya. Penelitian ${ }^{[2]}$ bahwa model experential learning diterapkan untuk mengembangkan pemahaman konsep. Komponen-komponen pemahaman yang dikembangkan meliputi menginterpretasi, 
memberikan contoh, mengklasifikasi merangkum, menduga, membandingkan, dan menjelaskan.

Model experiential learning berbasis eksperimen inquiry merupakan model pembelajaran melaui pengalaman dengan menggunakan metode eksperimen inquiry. Pengalaman yang akan membangun pemahaman dan ketermpilan siswa dalam menciptakan pengetahuan melalui kombinasi antara mendapatkan pengalaman dan mentransfomasi pengalaman ${ }^{[3]}$. Hal tersebut dapat dilakukan dengan melakukan eksperimen terhadap materi yang diajarkan. Siswa-siwa dapat dengan mudah memahami konsepkonsep yang rumit kondisi yang dihadapi dengan mempraktekkan sendiri upaya-upaya penemuan konsep melalui perlakuan terhadap pengatahuan, melalui penanganan bendabendanya.

\section{METODOLOGI PENELITIAN}

Penelitian ini menggunakan metode eksperimen kuasi, dengan desain penelitian "The Ekivalen Pretest-Posttest Design", yaitu memilih kelas-kelas yang diperkirakan sama kondisinya. Artinya tingkat kecerdasannya hampir sama, sehingga kelas yang satu dijadikan sebagai kelas eksperimen dan kelas yang satunya lagi dijadikan sebagai kelas kontrol. Bentuk desainnya disajikan pada Tabel 1.

Tabel 1 Desai Penelitian

\begin{tabular}{|l|c|c|c|}
\hline \multicolumn{1}{|c|}{ Group } & $\begin{array}{c}\text { Pre- } \\
\text { test }\end{array}$ & Perlakuan & $\begin{array}{c}\text { Post- } \\
\text { test }\end{array}$ \\
\hline $\begin{array}{l}\text { A(Eksperimen)B } \\
\text { (Kontrol) }\end{array}$ & 0 & $\mathrm{X}$ & 0 \\
\hline
\end{tabular}

Keterangan :

A : Kelas eksperimen

B : Kelas kontrol

O : Tes awal (pretest) dan tes akhir (posttest)

$X$ : Perlakuan untuk kelas eksperimen dengan menerapkan model experiential learning berbasis eksperimen inquiry

Pengelompokkan kategori persentase pemahaman konsep fisika, pada kelas eksperimen maupun kelas kontrol yang dikemukakan oleh ${ }^{4]}$ dapat dilihat pada Tabel 2.
Tabel 2 Kategori persentase pemahaman konsep

\begin{tabular}{|c|c|}
\hline Kategori & Persentase \\
\hline Sangat Tinggi & $80 \% \leq \mathrm{P}<100 \%$ \\
Tinggi & $60 \% \leq \mathrm{P}<80 \%$ \\
Sedang & $40 \% \leq \mathrm{P}<60 \%$ \\
Rendah & $20 \% \leq \mathrm{P}<40 \%$ \\
Sangat Rendah & $0 \% \leq \mathrm{P}<20 \%$ \\
\hline
\end{tabular}

\section{HASIL DAN PEMBAHASAN}

Uji Normalitas

Tabel 3 Hasil uji normalitas pretest dan posttest pada kelas eksperimen dan kelas kontrol

\begin{tabular}{|l|c|c|c|c|c|c|}
\hline \multirow{3}{*}{ Uraian } & \multicolumn{3}{|c|}{ Kelas Eksperimen } & \multicolumn{3}{c|}{ Kelas Kontrol } \\
\cline { 2 - 7 } & $\begin{array}{c}\text { Pre- } \\
\text { test }\end{array}$ & $\begin{array}{c}\text { Post- } \\
\text { test }\end{array}$ & $\begin{array}{c}\mathrm{N}- \\
\text { Gain }\end{array}$ & $\begin{array}{c}\text { Pre- } \\
\text { test }\end{array}$ & $\begin{array}{c}\text { Post- } \\
\text { test }\end{array}$ & N-Gain \\
\hline Jumlah & 18 & 18 & 18 & 19 & 19 & 19 \\
Siswa & & & 5,71 & 4,29 & 0,66 & 4,17 \\
$\chi^{2}$ hitung & 2,02 & 2,92 & 5,71 & 5,99 & 5,99 & 5,99 \\
$\chi^{2}$ tabel & 5,99 & 5,99 & 5,99 & 5,96 \\
\hline
\end{tabular}

Hasil uji normalitas kedua kelas pada Tabel 3 menunjukkan bahwa nilai $\chi^{2}$ hitung $<\chi^{2}$ tabel pada pretest, posttest dan rerata N-Gain. Berdasarkan data yang diperoleh sehingga pengambilan keputusan bahwa $\mathrm{H}_{0}$ diterima. Sampel dari kelas eksperimen dan kelas kontrol berasal dari populasi yang terdistribusi normal.

Uji Homogenitas

Tabel 4 Homogenitas dua varians pretest dan postest kelas eksperimen dan kelas kontrol

\begin{tabular}{|c|c|c|c|c|c|c|}
\hline \multirow{2}{*}{ Uraian } & \multicolumn{2}{|c|}{ Kelas Ekspe } & \multicolumn{2}{c|}{ Kelas Kontrol } & \multicolumn{2}{c|}{ N-Gain } \\
\cline { 2 - 7 } & $\begin{array}{c}\text { Pre- } \\
\text { test }\end{array}$ & $\begin{array}{c}\text { Post- } \\
\text { test }\end{array}$ & $\begin{array}{c}\text { Pre- } \\
\text { test }\end{array}$ & $\begin{array}{c}\text { Post- } \\
\text { test }\end{array}$ & $\begin{array}{c}\text { Ekspe- } \\
\text { rimen }\end{array}$ & $\begin{array}{c}\text { Kont- } \\
\text { rol }\end{array}$ \\
\hline $\begin{array}{c}\text { Nilai } \\
\text { rata- } \\
\text { rata }\end{array}$ & 16,78 & 33,67 & 16,11 & 24,32 & 24,00 & 50,00 \\
\hline$F_{\text {hitung }}$ & 1,61 & 1,08 & 1,61 & 1,08 & \multicolumn{2}{|c|}{2,09} \\
\hline$F_{\text {tabel }}$ & 2,23 & 2,19 & 2,23 & 2,19 & \multicolumn{2}{|c|}{2,19} \\
\hline
\end{tabular}

Berdasarkan hasil uji homogenitas pada Tabel 4 dengan taraf signifikansi $(a=0,05)$, menunjukkan bahwa $F_{\text {hitung }}$ pretest sebesar 1,61 , posttest sebesar 1,08 dan rerata gain sebesar 2,09. Nilai $F_{\text {tabel }}$ untuk pretest sebesar 2,23 dan posttes sebesar 2,19. Perbedaan nilai $\mathrm{F}_{\text {tabel }}$ karena pada pretest nilai standar deviasi kelas kontrol lebih besar dari kelas eksperimen. Pada posttest nilai standar deviasi kelas kontrol lebih kecil dari kelas eksperimen. Berdasarkan hasil perhitungan pretest dan posttest pada kelas eksperimen dan kelas kontrol diperoleh nilai $F_{\text {tabel }}$ rerata $\mathrm{N}$-Gain sebesar 2,19. Hasil pengolahan data menunjukkan bahwa $\mathrm{F}_{\text {hitung }}<$ $F_{\text {tabel }}$ sehingga dapat disimpulkan bahwa kelas eksperimen dan kelas kontrol pada tes awal dan tes akhir berasal dari variansi yang sama (homogen). 
Skor Pemahaman Konsep

Hasil perolehan skor rata-rata pretest dan posttest pemahaman konsep fisika dari kedua kelas dapat dilihat pada Gambar 1.

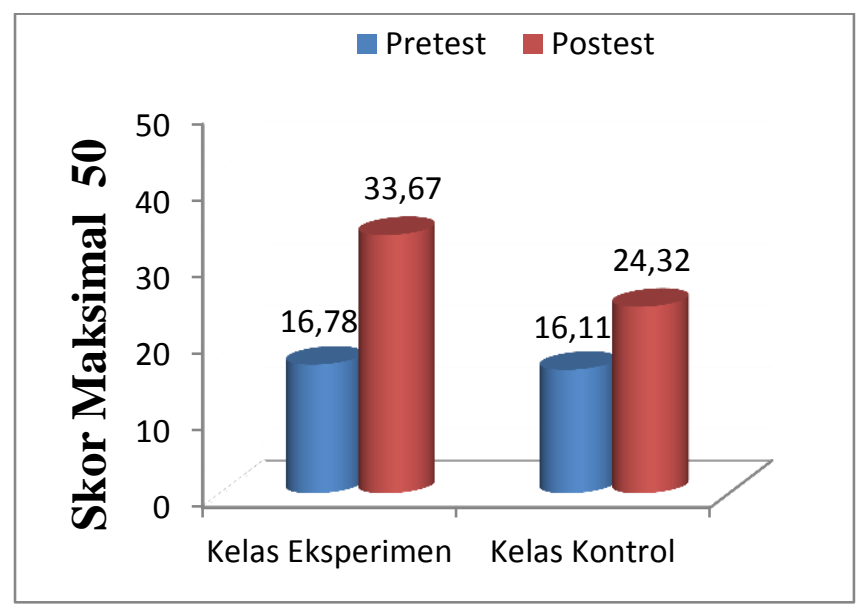

Gambar 1 Diagram perolehan skor rata-rata pretest dan posttest pemahaman konsep fisika

Berdasarkan Gambar 1 dapat dilihat bahwa pretest baik kelas eksperimen maupun kelas kontrol memiliki skor rata-rata yang relatif sama. Pada posttest untuk kelas eksperimen dan kelas kontrol memiliki perbedaan skor rata-rata yang relatif jauh yaitu pada kelas eksperimen sebesar 33,67 dan kelas kontrol sebesar 24,32. Hal ini menunjukan bahwa ada pengaruh model experiential learning berbasis eksperimen inquiry yang diterapkan pada kelas eksperimen.

Persentase Pemahaman Konsep Fisika

\section{Uji N-Gain}

Hasil perhitungan skor N-Gain siswa kelas eksperimen sebesar $50,00 \%$ dan kelas kontrol sebesar 24,00 \%. Kelas eksperimen termasuk dalam kategori sedang, dimana g > 30 dan kelas kontrol termasuk dalam kategori rendah, dimana $\mathrm{g}<30$. Berdasarkan analisis data kedua kelas mengalami peningkatan. Peningkatan yang terjadi menunjukkan bahwa kelas eksperimen lebih besar peningkatannya dibandingkan kelas kontrol.

Adapun perbandingan $\mathrm{N}$-gain dari kedua kelas dapat dilihat pada Gambar 3.

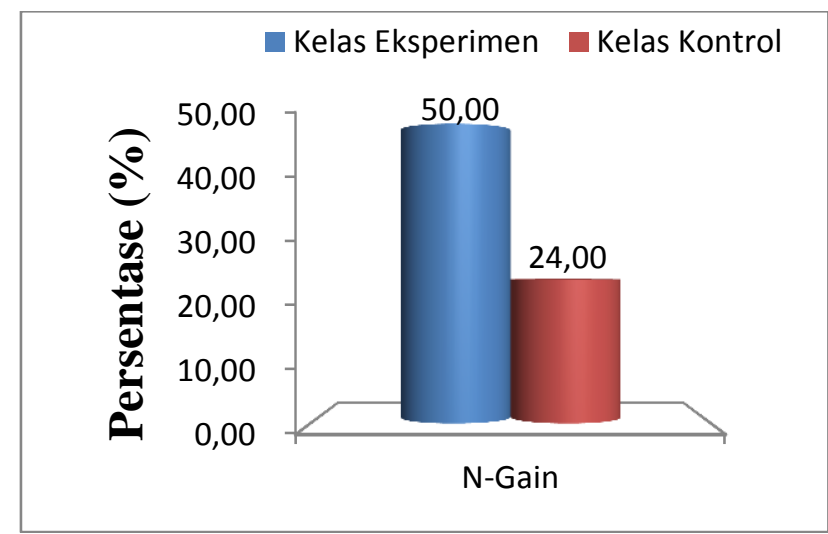

Gambar 3 Diagram perbandingan N-gain kelas eksperimen dan kelas kontrol.

Uji Hipotesis Posttest

Berdasarkan skor rata-rata posttest kelas eksperimen sebesar 33,67 dan kelas kontrol sebesar 24,32, dilakukan uji hipotesis (uji-t) uji satu pihak dan diketahui nilai $t_{\text {hitung }}=$ 7,42. Dari daftar distribusi t diperoleh harga $t_{\text {tabel }}=1,68$ Hal ini berarti $\mathrm{H}_{0}$ ditolak sedangkan $\mathrm{H}_{1}$ diterima.

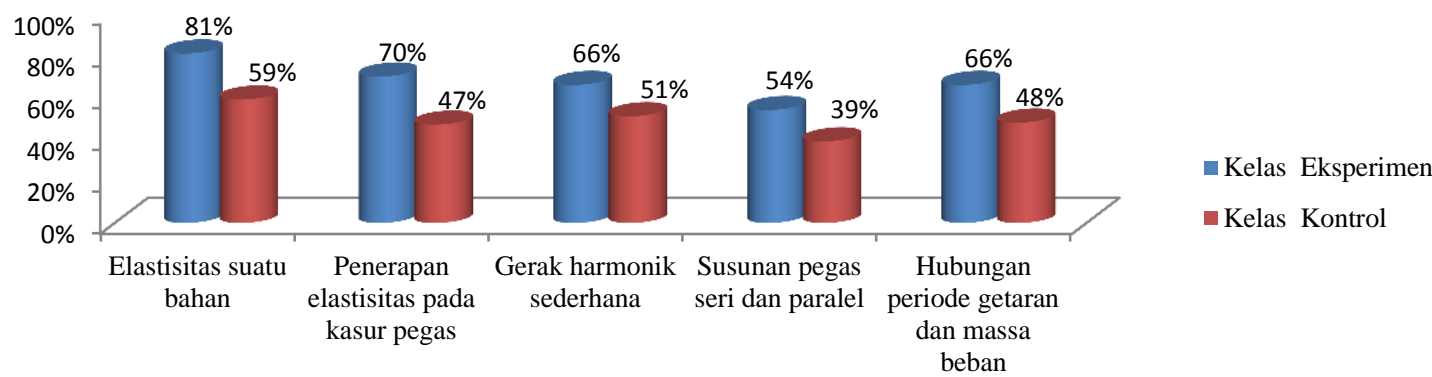

Gambar 2 Diagram persentase pemahaman konsep fisika pada posttest kelas eksperimen dan kelas kontrol

Berdasarkan Gambar 2 dapat dilihat
bahwa terdapat perbedaan persentase pemahaman konsep fisika pada posttest kelas eksperimen dan kelas kontrol yang relatif jauh.
Dengan demikian, dapat disimpulkan bahwa ada pengaruh model experiential learning berbasis eksperimen inquiry terhadap pemahaman konsep fisika siswa. 
Hasil analisis data posttest pada kelas eksperimen dan kelas kontrol terdapat perbedaan persentase pemahaman konsep fisika siswa relatif jauh yang ditunjukkan pada Gambar 2. Berdasarkan ketentuan kategori persentase pemahaman konsep fisika yang dikemukakan oleh ${ }^{[4]}$, hasilnya menunjukkan bahwa persentase pemahaman konsep fisika dalam kategori sangat tinggi hanya dapat dicapai oleh kelas eksperimen pada konsep elastisitas suatu bahan. Selanjutnya untuk kategori tinggi ada tiga konsep yakni konsep penerapan elastisitas pada kasur pegas, gerak harmonik sederhana dan hubungan periode getaran dan massa beban.

Pada konsep susunan pegas seri dan paralel berada pada kategori sedang karena sebagian besar siswa menjelaskan pertambahan panjang pegas pengganti yang lebih besar adalah yang berbentuk seri karena pegasnya tersusun kebawah sehingga pegas yang dekat dengan beban akan memiliki beban yang lebih banyak. Konsep yang sebenarnya adalah pertambahan panjang pegas pengganti lebih besar adalah susunan pegas seri yaitu pertambahan panjang pegas pengganti seri sama dengan total pertambahan panjang tiaptiap pegas $\left(\Delta \mathrm{x}_{\mathrm{S}}=\Delta \mathrm{x}_{1}+\Delta \mathrm{x}_{2}\right)$. Sedangkan pada susunan pegas paralel yaitu pertambahan tiap pegas sama besar dan pertambahan panjang sama dengan pertambahan panjang pegas pengganti. Oleh karena itu, sebagian siswa mengalami miskonsepsi pada konsep susunan pegas seri dan paralel. Menyebutkan bahwa 'salah satu sumber kesulitan utama dalam pelajaran fisika adalah akibat terjadinya kesalahan konsep atau miskonsepsi pada diri siswa ${ }^{[5]}$. Mengungkapkan bahwa siswa yang berminat rendah terhadap fisika cenderung memiliki miskonsepsi yang lebih tinggi dibandingkan dengan siswa yang berminat tinggi ${ }^{[6]}$.

\section{Pengelompokkan}

persentase pemahaman konsep untuk kelas kontrol, berdasarkan hasil penelitian dan pengolahan data tidak ada yang mencapai kategori sangat tinggi dan kategori tinggi. Pada kategori sedang terdapat empat konsep yaitu elastisitas suatu bahan, penerapan elastisitas pada kasur pegas, gerak harmonik sederhana, dan hubungan periode getaran dan massa beban. Untuk kategori rendah terdapat satu konsep yaitu susunan pegas seri dan paralel.
Uraian di atas menunjukkan bahwa dari hasil penelitian ada pengaruh model experiential learning berbasis eksperimen inquiry terhadap pemahaman konsep fisika pada kelas eksperimen dibandingkan dengan kelas kontrol yang menggunakan model konvensional. Hal ini ditunjukkan pada kelas eksperimen kategori pemahaman konsep, tidak ada pada kategori rendah. Bahkan pemahaman konsep siswa setelah menggunakan model pembelajaran ini mencapai kategori sangat tinggi.

Pernyataan tersebut didukung oleh penelitian-penelitian sebelumnya Aryanta ${ }^{[7]}$. Hasil penelitiannya proses belajar mengajar yang lebih merangsang siswa karena setiap proses pembelajaran siswa selalu aktif berpikir dan siswa diberi kebebasan berinisiatif. Hal ini terlihat dari sikap bertanya, menanggapi, dan menyanggah dari siswa dalam setiap kegiatan pembelajaran melalui diskusi kelompok, sehingga pemahaman konsep dan kemampuan berfikir kritis siswa berkembang. Hasil penelitiannya menunjukkan bahwa mencakup empat aktivitas pemecahan masalah secara urut yaitu merumuskan hipotesis, merancang eksperimen, melakukan eksperimen, menemukan konsep dari hasil eksperimen, dan menghubungkan konsep dengan kehidupan sehari-hari ${ }^{[8]}$. Setelah kegiatan eksperimen banyak pertanyaan yang disampaikan siswa mengenai hasil eksperimen tersebut, hal meningkatkan pemahaman konsep siswa dan sikap ilmiah siswa.

\section{Motivasi belajar dan pemahaman} konsep fisika melalui model experiential learning menekankan pada proses belajar, yang menggunakan pengalaman kehidupan siswa dalam belajar, sehingga tercipta suasana belajar yang menyenangkan dan kondusif ${ }^{[9]}$. Hasil penelitiannya menunjukkan guru membimbing siswa memberikan penjelasan konseptual terhadap kegiatan yang telah dilakukan dengan menggunakan pertanyaanpertanyaan tuntunan ${ }^{[10]}$. Untuk mengetahui tingkat pemahaman konsep siswa, guru memberikan pertanyaan-pertanyaan yang link dan match dengan pengalaman yang diperoleh sebelumnya.

Berdasarkan hasil penelitian, maka dapat diambil kesimpulan ada pengaruh model experiential learning berbasis eksperimen inquiry dibandingkan model pembelajaran 
konvensional. Adapun beberapa alasan yang dapat dijadikan dasar justifikasi peneliti dapat mengemukakan kesimpulan terjadinya perbedaan antara kelas eksperimen dan kelas kontrol, karena dalam proses pembelajaran experiential learning berbasis eksperimen inquiry pada kelas eksperimen siswa dihadapkan dengan permasalahan nyata yang membangkitkan rasa keingintahuan untuk melakukan penyelidikan sehingga dapat meningkatkan keterampilan-keterampilan berpikir, menumbuhkan inisiatif siswa dalam bekerja, motivasi internal untuk belajar, dan dapat mengembangkan hubungan dalam bekerja kelompok, pada akhirnya dapat menemukan sendiri jawaban atau konsep.

Siswa pada kelas eksperimen lebih terlatih dalam menyelesaikan masalah yang menyangkut pembelajaran fisika, dalam materi elastisitas dan gerak harmonik sederhana. Secara tidak langsung mereka telah melakukan pengembangan pola berpikir kritis, memprediksi, melakukan eksperimen, menemukan konsep dan mengolah data. Selain itu, siswa meganalisis dan membuat kesimpulan terhadap konsep yang ditemukan serta dapat memahami konsep tersebut. Siswa menjadi aktif berpikir dan komunikatif, sehingga model pembelajaran experiential learning berbasis eksperimen inquiry sangat membantu siswa dalam menyelesaikan masalah yang sangat membutuhkan dalam memahami konsep.

Berbeda dengan pembelajaran konvensional dalam hal ini kelas kontrol yang menggunakan metode ceramah, guru yang aktif memberikan pengetahuan, sementara siswa hanya menerima. Kebanyakkan siswa merasa tidak berani bahkan tidak percaya diri untuk bertanya atau pun mengemukakan pendapatnya. Apabila terus berlanjut maka cara berpikir siswa pun hanya terbatas pada apa yang guru sampaikan selama proses pembelajaran. Suasana belajar yang seperti itu cenderung monoton sehingga siswa menjadi bosan dan tidak termotivasi dalam belajar. Hal inilah yang menyebabkan kemampuan pemahaman konsep fisika siswa di kelas kontrol sangat kurang.

Kelebihan dari model pembelajaran ini dibandingkan dengan pembelajaran langsung adalah keaktifan siswa. Melalui model pembelajaran ini siswa dilibatkan untuk aktif berfikir dan menemukan secara langsung pengertian atau konsep yang ingin diketahuinya. Selain dari kelebihan tersebut, adapula kekurangan dari model ini yaitu membutuhkan waktu yang cukup lama dalam bereksperimen untuk memperoleh kesimpulan atau suatu konsep yang utuh. Sehingga, dari hasil analisis skor rata-rata yang diperoleh masih dalam kriteria rendah, karena masih terdapat beberapa siswa yang melakukan aktivitas lain pada saat bereksperimen. Kita sebagai guru (fasilitator) juga butuh kesabaran yang lebih dalam membimbing siswa agar dapat fokus dalam melakukan kegiatan pembelajaran.

\section{KESIMPULAN}

Hasil pengujian N-Gain kelas eksperimen berada dalam kategori sedang dengan nilai $\mathrm{N}$ gain sebesar $50,00 \%$ dan kelas kontrol berada dalam kategori rendah dengan nilai N-Gain sebesar 24,00 \%. Hasil pengujian hipotesis diperoleh nilai $t_{\text {hitung }}>t_{\text {tabel }}(7,42>1,68)$. Hal ini berarti $\mathrm{H}_{1}$ diterima dan $\mathrm{H}_{0}$ ditolak. Dengan demikian dapat disimpulkan bahwa ada pengaruh model experiential learning berbasis eksperimen inquiry terhadap pemahaman konsep fisika pada siswa kelas XI IPA MAN 1 Palu.

\section{DAFTAR PUSTAKA}

[1] Rina Lestari. N.W. Pengaruh Model ExperientialLearning Terhadap Keterampilan Berpikir Kritis Dan Motivasi Berpretasi Siswa. Skripsi. Universitas Ganesha : Tidak Ditererbitkan.

[2] Ari Anggara, I K. 2011. "Pengaruh Model PembelajaranExperientia Terhadap Konsep Diri Dan Pemahaman Konsep Fisika Siswa Kelas X SMA Negeri 4 Singaraja". Jurnal Pendidikan Dan Pengajaran UNDIKSHA,

[3] Kolb, A. Y., \& Kolb, D. A. (2005). Learning Style And Learning Spaces:Enhancing Experimental Learning In Higher Education. Tersedia Pada Http://Www.Learningfromexperience.

Com/Research-Library/ Diakses Pada Tanggal 03 Januari 2015.

[4] Arikunto, S. (2009). Dasar - Dasar Evaluasi Pendidikan. Jakarta : PT Bumi Aksara.

[5] Berg, Van den E. (Ed). (1991). Miskonsepsi Fisika dan Remediasi. Salatiga : Universitas Kristen Satya Wacana.

[6] Suparno, Paul. (2005). Miskonsepsi dan Perubahan Konsep Pendidikan Fisika. Jakarta: Grasindo. 
[7] Aryanta, I K D. (2011). Pengaruh Pembelajaran Experiential dan Gaya Kognitif Terhadap Pemahaman Konsep dan Kemampuan Berfikir Kritis Pada Pokok Bahasan Kalor dan Pemuaian. Tesis. (tidak diterbitkan). Studi Pendidikan Sains, Program Pascasarjana, Universitas Pedidikan Ganesha.

[8] Mawarsari, A.A. (2013). Penerapan Metode Eksperimen Berpendekatan Inkuiri untuk Meningkatkan Pemahaman Konsep dan Sikap Ilmiah Siswa. Universitas Negeri Malang : diterbitan.

[9] Wahyuningsih, Dwi. (2014). Motivasi Belajar dan Pemahaman Konsep Fisika Siswa SMK dalam Pembelajaran Model Experiential Learning. Skripsi pada Universitas Jember : diterbitkan.

[10] Kasni, I.W., Pudjawan, Kt \& Agustiana, Tri. I G.A. (2014). Pengaruh Model Pembelajaran Experiential Terhadap Prestasi Belajar IPA di Kelas V SD Kelurahan Kaliuntu. Laporan Penelitian (tidak diterbitkan). Universitas Pendidikan Ganesha Singaraja Indonesia. 